\title{
The Effects of Multisensory- Based Instruction Combined with Brain-Compatible Environment Techniques on Reading Fluency and Reading Comprehension of Fourth-Grade Students with Dyslexia
}

Mohammad Said Soliman' and Feras Mohammed Al-Madani ${ }^{2}$ 'Special Education Department, Faculty of Arts and Education, Northern Border University

${ }^{2}$ Curriculum and Instruction Department, Faculty of Arts and Education, Northern Border University

\section{Abstract}

The main goal of the present study was to examine the effects of multisensory-based instruction combined with brain-compatible environment techniques on the reading fluency and comprehension of Arabic $4^{\text {th }}$ grade students with dyslexia. Participants were 38 students with dyslexia, divided into two groups: one with 18 students who received intervention (experimental group), and the other with 18 students who received no intervention (control group). The Reading Fluency Test and Reading Comprehension Test were used to measure reading fluency and comprehension in pre- and post-tests. The training was conducted in the experimental group with dyslexia in 70 training sessions. Results showed that there were statistically significant differences in post-tests of reading fluency and reading comprehension between the control and the experimental groups, in favour of the experimental group, and statistically significant differences in the experimental group between the results of the pre-and post-tests, in favour of the post-test of reading fluency and reading comprehension. The discussion focuses on future directions for research on reading interventions for dyslexic students.

Key words: brain-compatible learning; dyslexia; multisensory approach; reading comprehension; reading fluency. 


\section{Introduction}

Reading efficiency is an academic skill that plays an important role in success at school. The ability to read efficiently and fluently is one of the requirements necessary for effective professional performance. Therefore, the future of students largely depends on their ability to read well and acquire this skill. Teaching reading is therefore one of the most important tasks in public education, especially in the early stages of learning. It is indeed one of the most important skills students should learn at school. Swanson (1999) stresses that reading is necessary for most academic fields and compatible with most school activities; learning and mastery of reading is of the utmost importance. Zidan Al-Sartawi (2006) mentions that developing the skill of reading is considered to be the most important of all skills learned at school. According to Soliman Al-Sayed (2005), reading is an important prerequisite for academic achievement, so reading-impaired children usually do not perform well academically. For Chard et al. (2009), learning how to read efficiently remains the most important skill that determines the degree of students' success in academic achievement at school. Failure to learn how to read, particularly in the early stages of learning, results in significant adverse effects that extend to all aspects of cognitive, emotional and behavioural growth of the learner, if not treated properly. This can be done by categorising that student under a specific level of reading suited to his/her abilities and aptitude.

According to official reports, there is a significant increase in the number of pupils who have reading disabilities. Dyslexia is the commonest reading disability, especially in primary schools. Reading disabilities affect roughly $80 \%$ of the learningdisabled population (Hudson, High, \& Otaiba, 2007; Lyon, Shaywitz, \& Shaywitz, 2003). In this population, dyslexia is the most common learning disability (Torgesen Wagner, Rashotte, Herron, \& Lindamood, 2010; Wajuihian \& Naidoo, 2012). It is widely recognised as a neurological disorder with dysfunction of the left-hemisphere language network (Eden \& Moats, 2002; Gabrieli, 2009; Goswami, 2006; Peterson \& Pennington, 2012; Price \& Mechelli, 2005; Schlaggar \& McCandliss, 2007). It is characterised by specific impairments in the acquisition of efficient reading and emerges despite normal intelligence, the absence of obvious sensory deficits, and adequate instruction (Lyon et al., 2003). Among primary school pupils, dyslexia is clearly manifested as a deficiency in one or more skills of the so-called lower level: word identification and phonological awareness or phonological processing; as well as higher-level skills such as reading comprehension, which is the end result of the reading process. In order for learners to acquire the skill of reading comprehension and be familiar with vocabulary, they should first become highly competent at the lower level, i.e. identification skill that should function automatically and accurately. This skill is one of the main reasons for students' poor reading comprehension, as proved by Aaron et al. (1999), Catts et al. (1999), Cutting \& Scarborough (2006), Leach et al. (2003), Shankweiler (1999) and Torgesen (2002). 
Consequently, many researchers find that treating the deficiency at lower-level identification skills is an important prerequisite for improving reading comprehension among students suffering from dyslexia in training programs for improving comprehension skills. This is an essential requirement, especially if the student's disability in word identification is clear. Moreover, the sooner the treatment begins, the better the expected results will be (Chard, 1999; Pogorzelski \& Wheldall, 2002; Torgesen, 2000).

The literature on reading disabilities points to a substantial and decisive skill related to dyslexia, which should be considered when designing the necessary treatment programs. But this skill - reading fluency - is usually ignored when teaching reading or treating its problems. A good reader should read smoothly and fluently, and be able to quickly identify words without looking at them for a long time. Compton \& Carlisle (1994) state that many theories of efficient reading development emphasise the central role of teaching how to read words accurately, fluently and smoothly; the precise identification of words provides the reader with ways of understanding ideas in the text, which takes place when this process is done quickly enough, allowing the reader to extract the text meaning. The same view is stressed in studies by Ebner \& Miller (2003), Hudson (2005), and Richards (2000). A study conducted by the National Assessment of Educational Progress (NAEP) found that $44 \%$ of students in the $4^{\text {th }}$ grade were dysfluent in grade-level stories. A previous study also found that students who struggle with reading fluency also struggle with reading comprehension (Pinnell, Pikulski, Wixson, Campbell, Gough, \& Beatty, 1995).

Based on what has already been mentioned, when treating students with reading disabilities, one should take into consideration a number of elements: increasing the speed and accuracy of dyslexic students, as well as their reading fluency, so as to give them a sense of achievement, which affects their reading comprehension later.

To sum up, it is clear that dyslexic students mainly have problems with word identification and fluency. Both affect their understanding of the text they are reading because they slowly identify words. Since most of their attention is spent on that level, meanings are not extracted. The question remains what is the most effective strategy for improving reading fluency and reading comprehension, particularly considering the various strategies known to stimulate reading fluency and help dyslexic children improve their reading skills (Duff \& Clarke, 2011). Many of these strategies have focused on interventions designed to improve students' phonological or word-level abilities. Some researchers caution that focusing on these skills "may actually contribute to reading failure by diverting the child's attention away from more productive strategies" (Tunmer \& Greaney, 2010, p. 234). There are multiple and various methods and strategies used for the treatment of dyslexia. There is one strategy that has not received adequate attention in Arabic and international studies on therapy and training: it is called the multisensory teaching strategy. Within reading teaching, the term "multisensory" refers to techniques for novice or struggling readers involving 
visual, auditory, tactile, and motor components embedded in a carefully sequenced program based on the structure of language and linguistic knowledge (Moats \& Farrell, 2005). Learners learn best if they use all their senses, which also helps ingrain new knowledge in memory (Cohen, 2001). Cognitive neuroscience lends theoretical support for the use of multisensory teaching based on the way memory works:

[I]t is easier to integrate multiple sources of information during learning when the material is physically integrated, auditorily and visually, than when information is presented to each modality separately. (Mousavi, Low, \& Sweller, 1995, p. 319)

Many empirical studies have investigated the effectiveness of multisensory teaching in developing reading skills of elementary school dyslexic students (Chuen, 2005; Foorman et al., 1997; Heidari et al., 2012; Hook et al., 2001; Jeyasekaran, 2015; Joshi et al., 2002; Kutrampos, 1993; Mehrabi et al., 2014; Nourbakhsh, 2014; Oakland et al., 1998; etc.).

On the other hand, brain-based learning (BBL) is a new trend in education. BBL is based on the results of neurology research applied in the field of education. This approach was designed in a way that makes it compatible with the structure, tendency and optimum function of the human brain, to ensure the effectiveness of the individual learning process (Caine \& Caine, 1991, 2003; Jensen, 1996; Sousa, 1995). The hypothesis that learning causes neuroanatomical changes which can correct neurological dysfunctions that are the basis of dyslexia by forming new synapses, has been proven by numerous researchers over the past decades (Bigler, 1990; Goldman-Rakic, 1992; Lynch \& Baudry, 1984; Myers \& Hammill, 1990). Based on this hypothesis, the BBL approach may be more appropriate for students with dyslexia, when environmental, emotional, physiological and hemispheric factors that affect the learning process are taken into account. According to BBL, movements, breaks, enriched environment free of stress, fears, and tensions, positive emotions, ongoing feedback, providing bottles of water, pleasant smiles and natural relaxed music are important elements for producing new synapses that lead to the establishment of new neural networks as a compensatory strategy (Moats \& Farrell, 2005). This supports the effectiveness of using BBL strategies to create an optimal learning environment that suits the brains of pupils with dyslexia.

Hence, the present study tests the effectiveness of using the multisensory teaching strategy combined with brain-compatible environment for increasing the reading fluency and comprehension of $4^{\text {th }}$ grade dyslexic students.

\section{Study Statement}

According to official statistics, the number of students with reading disabilities in primary schools is increasing and raising concern. Statistics show that this increase is likely to be much higher in developing societies such as the Saudi society, especially with overcrowded classes at schools and busy teachers with insufficient skills and abilities. 
Al-Saeed (2001) and Al-Sartawi (2006) mention that the pupils with reading disabilities make up 10-15\% of schoolchildren. Soliman (2005) mentions an estimated $20 \%$ increase in poor reading skills among primary school pupils, which raises concern. These numbers are likely to increase because of the lack of care and treatment opportunities for those pupils in the early stages of the disability (especially in lower grades). On the other side, the relevant literature indicates a deficiency of a number of sub-skills, which leads to a decline in the level of reading fluency and reading comprehension. Chard et al. (2009) argue that efficient reading can be characterised as a multi-faceted process that includes word identification (or decoding) and comprehension.

Many therapeutic strategies have been used to address this problem among students with reading disabilities. Examples include strategies of Repeated Reading, Reading Theatre, and Choral Reading. Most studies have not applied follow-up tests to investigate long-term effects of the abovementioned strategies. The authors presume that the results of follow-up tests might have discovered a decline in reading fluency and reading comprehension. This might be due to the fact that these strategies were not based on an integrated model that takes into account the psychological, physiological, cognitive and social aspects of learning. Researchers were therefore keen on finding solutions for these problems and looked for the most effective strategies that can develop reading fluency. In studies conducted in this area, one important and basic technique proved to increase reading fluency at word level for students with reading disabilities, although it did not receive adequate attention among researchers in the Arab world - teaching with the multisensory strategy. Many empirical studies have tested the effectiveness of multisensory teaching in developing reading skills of dyslexic students.

Jeyasekaran (2015) examined the effectiveness of the visual, auditory, kinaesthetic, and tactile (VAKT) technique on reading levels among children with dyslexia studying at Helikx Open School and Learning Centre, India. Thirty subjects were selected by using the purposive sampling technique. The intervention VAKT technique and the Schonell Graded Word Reading Test were used as tools in the study. The intervention VAKT technique was used for children with dyslexia for 30 consecutive days and followed by a post-reading level assessment. The finding shows that the mean percentage of the reading level was improved by $12 \%$ after the intervention. It also shows that there is a significant statistical difference before and after the intervention at the level of $\mathrm{p}<0.05$. This shows that the VAKT technique is significantly effective in improving the reading level among children with dyslexia.

Nourbakhsh (2014) examined the effects of the multisensory method and cognitive skill training interventions on the reading ability of dyslexic students in Iran. Sixty third-grade dyslexic students who participated in this study were divided into three experimental groups, with 20 dyslexic students in the first experimental group (E1), 20 dyslexic students in the second experimental group (E2), and 20 dyslexic students 
in the control group (C). The author used 16-week interventions, reading and dyslexia tests, the Bender Visual-Motor Gestalt Test, and the Rorschach test. Findings demonstrated that both groups (E1 and E2) improved from pre- to post-intervention; however, the two groups significantly improved their perceptual performances in reading and dyslexia tests.

Mehrabi et al. (2014) examined the effects of the multisensory teaching method by using the Sina educational instrument to measure reading and writing in learningdisabled children in the city of Tonekabon (Iran). The study sample included 30 randomly selected children with reading and writing disabilities. They were randomly divided into two groups: the experimental and control group. In order to collect data, reading and dyslexia (NAMA), writing (spelling) tests and the Wechsler Intelligence Scale for Children (WISC-R) were used. The experimental group participated in weekly 45 -minute sessions of structured training during 13 weeks. The results showed that the Sina multisensory teaching method improved reading and writing of children with learning disabilities.

Gorjian, Alipour, \& Saffarian (2012) investigated the effects of multisensory techniques on reading comprehension (RC) through multisensory modalities including visual, tactile, auditory, and motor modalities. The participants were selected based on their homogeneous scores on the RC proficiency test. The experimental group was taught RC through multisensory techniques, while the control group received some placebos on RC. Data was collected with pre- and post-tests which lasted for 12 sessions. Findings revealed significant differences between the two groups, since the experimental group outperformed the control group in RC in the post-test phase.

The study by Heidari et al. (2012) aimed to compare the effectiveness of the Davis and Fernald methods on the reading performance of third-grade elementary school students with dyslexia. The statistical population included dyslexic children who were referred to the Shenakht and Alefba Zendegi Isfahan city clinic in December 2011. The research sample was selected through convenience sampling: among the children referred to this clinic, 45 were selected as the final sample and randomly separated into two experimental and control groups (15 students in the Fernald method experimental group, 15 students in the Davis method experimental group and 15 students in the control group). Assessment tools included the Reading Test (RT) and the Wechsler Intelligence Scale for Children (WISC-IV). Intervention was applied in the two experimental groups: ten 30-minute sessions in the Fernald method group, and sixteen 30-minute sessions in the Davis method group. The SPSS-15 software was used to record the post-test scores and analyse the data. Results of the covariance analysis show a significant difference between the mean scores of the reading test in the experimental groups and the post-test in the control group, in favour of the Fernald method experimental group.

Chuen (2005) investigated the effectiveness of incorporating multisensory as well as computer-assisted learning techniques into the "Focused Word Recognition Method" 
to teach children with dyslexia the accuracy of reading and writing in Chinese. Participants were six second-grade elementary school students participating in the Intensive Remedial Teaching Programme (IRTP). The training was conducted in ten sessions, from January to March 2003. Results of the pre- and post-tests showed that participants significantly improved their accuracy of writing and reading Chinese character.

On the other hand, in the past decade there was a hypothesis saying that learning produces morphological-neurological changes that can correct neurological disorders which cause dyslexia by forming new synapse points. This hypothesis has been proved (Bigler, 1990; Goldman-Rakic, 1992; Lynch \& Baudry, 1984; Myers \& Hammill, 1990). It supports the effectiveness of using a brain-based learning strategy to create an optimal learning environment that suits the brains of students with dyslexia. Empirical studies examining the effectiveness of the brain-based learning approach in identifying effective interventions for students with dyslexia are limited.

To sum up, the present study has one main question to answer: How effective is a training program based on the multisensory approach combined with a braincompatible environment in increasing reading fluency and reading comprehension among $4^{\text {th }}$ grade dyslexic students? There are two sub-questions as well:

1 - Are there statistically significant differences between the average scores of both the experimental and control group students in post-tests of reading accuracy, reading speed and reading comprehension, after the pre-test influence has been eliminated?

2 - Are there statistically significant differences between the average pre- and posttest scores of the experimental group in reading accuracy, reading speed and reading comprehension?

\section{Significance of the Study}

The study is concerned with $4^{\text {th }}$ grade dyslexic students. Fourth grade students are supposed to read efficiently in a way that suits the nature of this educational phase, after which they are exposed to many diverse and advanced academic experiences. It is one of the studies that deal with this problem at this critical stage in the education life of students. The treatment of this problem helps largely determine their educational and vocational future. The study addresses a neglected skill in teaching reading: the skill of reading fluency. Generally speaking, teachers do not take this skill into account when they teach reading and as far as the authors know, this skill has not been duly and adequately studied. The present study may draw the attention of researchers and educators to research and investigate this neglected reading skill, especially in the Arabic environment. The study suggests researching the proposed strategy in the field of reading in the Arabic environment and sheds light on it to determine how effective it is for improving reading fluency of dyslexic students. It attempts to draw the attention of researchers to that strategy so that they may take it into account in experimental 
designs concerned with improving poor reading skills or teaching reading itself. The results of the study can have educational applications for those interested in the field of reading disabilities, when cases similar to the sample used in this study are found.

\section{Method}

\section{Participants}

Fourth-grade primary school students with dyslexia who were referred to the Specific Learning Disability Centre belong to four schools which participated in the study. Participants were selected from referrals made by ordinary schools to the public Specific Learning Disability Centre. The diagnostic standards used in the Centre were in accordance with the Diagnostic and Statistical Manual of Mental Disorders ( $4^{\text {th }}$ edition, DSM-IV) of dyslexia. Criteria for participation in the study were that the dyslexic children: (1) did not have a prior history of treatments for dyslexia; (2) met the criteria of DSM-IV of dyslexia, including: (a) accuracy and/ or fluency word recognition difficulty; (b) word decoding deficiency; (c) reading rate problem; (d) prosody weakness; and (e) reading comprehension difficulty; (3) had scores of 80 or higher on tests of intelligence; (4) met the average T-score of 70 or above on four subscales in the Dyslexic Diagnostic Test; (5) were free from reported neurodevelopmental disorder, hearing and vision disorders, or any other major handicap; (6) spoke Arabic as a first language, and were right-handed because of the effects of handedness of cognitive ability (Benbow, 1986; McManus, 2002; Resch et al., 1997). From this sample, 36 students matched the indicators listed above (mean age $=10.21, \mathrm{SD}=1.024)$. The researchers divided the selected participants into an experimental (mean age $=10.34, \mathrm{SD}=1.329)$ and control group (mean age $=9.85$, $\mathrm{SD}=0.476$ ), with 18 male students in each group.

\section{Measures}

The Dyslexia Diagnostic Test (DDT) was standardised by Nassra Glgl from Tanta University (2008). It is an individually or group administrated test for diagnosing the reading ability of students with dyslexia. The test consists of 80 items distributed on four dimensions which evaluate reading ability, including word recognition, word comprehension, sentence comprehension, and passage reading comprehension. Each response in this test is considered as one score. Internal consistency (determined with Cronbach's Alpha) for the test was 0.72 .

Raven's Coloured Progressive Matrices is internationally recognised as a culturefair or culture-reduced test of non-verbal measure of intelligence for young children (Raven et al., 1990). It is a standardised test which consists of 36 items which are divided into three sets: A, B, and AB, each set consisting of 12 items. Each item is a geometrical shape presented on a coloured background; one part of the shape is missing and the participant is asked to select the missing part out of six options. The problems are easy at first, but become more difficult as the test proceeds. 
Reading Fluency Test (RFT). Researchers established this test in light of tests described in theoretical literature and related studies such as Good \& Kaminski's test (2002). Two combined oral reading scores were taken: text reading speed and text reading accuracy. The former score was calculated by dividing the number of words read correctly by the total time needed to read the passage expressed in seconds, multiplied by 60 (Parker, Hasbrouck, \& Tindal, 1992). Text reading accuracy was calculated by dividing the number of words read correctly by the total number of words read and multiplying this result by 100 (Parker et al., 1992). Students had to read aloud an appropriate 190-word text written in font 16. In order to identify the content validity of the test, opinions of nine specialists in the fields of curriculum and instruction, and special education were applied. The internal consistency of the RFT, calculated with Cronbach's Alpha Coefficient, was 0.86 .

Reading Comprehension Test (RCT). The test is designed to measure reading comprehension by reading a narrative text, accompanied by a set of multiplechoice questions. Students are required to read the text in silence and answer 10 multiple-choice questions. The researcher relies on the following levels of reading comprehension to prepare the test: literal comprehension, interpretive comprehension, reasoning comprehension, and evaluation comprehension. In order to identify the content validity of the test, opinions of nine specialists in the fields of curriculum and instruction, and special education were applied. The internal consistency of the RCT, calculated with Cronbach's Alpha Coefficient, was 0.74.

\section{Procedures}

Participants were divided into two groups: the experimental (18 students) and control group (18 students). Reading fluency and reading comprehension tests were conducted in both groups as pre-tests. The physical environment was modified so as to be compatible with brain-based learning principles. The intervention was applied in the experimental group, while the traditional method was applied in the control group. Reading fluency and reading comprehension tests were conducted in both groups as post-tests.

\section{Intervention}

The project was conducted for 14 weeks with two groups: the experimental and control group. Multisensory-based instruction has taken about 70 sessions. The intervention was multisensory-based instruction, which used visual, auditory, tactile, kinaesthetic, olfactory and gustatory senses in reading. For students with reading difficulties, learning to learn is an ongoing process. Participants in the experimental group engaged in multisensory intervention with the first researcher in 60-minute sessions. Prior to each session, the researcher conducted an informal assessment of the students' senses. The strategy started with students selecting one passage from a 
group of previously determined passages. Students' choices were introduced as a way to motivate them to do their best while reading (Guthrie et al., 2006). Once the passage was selected, students - in groups of three - engaged in the following exercises:

Revision of graphemes for each word in the selected passage was applied. The researcher used explicit teaching to clarify the relationship between phonemes and graphemes. Direct teaching of phoneme-grapheme relationships enhances decoding abilities, especially among dyslexic students (Uhry \& Clark, 2005). The researcher used the explicit teaching approach because of the phonological deficits of dyslexic students.

Visual and auditory drill: the researcher showed each word in the selected passage on a flashcard and modelled it loudly. Students repeated the word five times.

Tactile, kinaesthetic, auditory, visual blended drill: students formed each word in the selected passage by using magnetic letters. They traced it with their index fingers saying the sounds while doing so. The pervious exercise was repeated five times.

Smell and taste drill: since smells and tastes linger in the brain far longer than other kinds of memory and have been shown to influence health, belief, behaviour, attitudes, and productivity, the researcher used those senses in the intervention. Each letter of the Arabic alphabet was perfumed with a natural scent such as lemon, jasmine, narcissus, and musk. A combination of floral scents has been shown to double the speed of learning (Wilmes et al., 2008). Students chose the scented letters that were compatible with their preferences, and then formed words on a magnetic board. They traced the letters with their index fingers, saying the sounds while doing so. Students traced each word in a sand tray with their index fingers and then wrote them in the air while saying the corresponding sounds out loud. Each word was configured by using desserts with a variety of flavours such as mango, orange, apricot, strawberry, banana, and chocolate. Students then grouped words from the selected passage according to their preferences in flavours. Finally, students traced the word saying the sounds while doing so.

After practicing the previous exercises, the researcher selected a short passage to help students practice reading words in context, and reading and understanding short passages. Students used their fingers to point to each word. The researcher asked comprehension questions according to reading comprehension levels that include literal comprehension, interpretive comprehension, reasoning comprehension, and evaluation comprehension. For the control group, the researcher showed words on a board and modelled individual words loudly. Students repeated each word, saying it slowly then fast. The researcher wrote words in short sentences, and then modelled reading sentences aloud. The researcher read a passage out loud twice. Peers read every passage several times. The researcher explained the passage by providing the meanings of individual words. He asked students to create sentences that include the meaning of individual words. 
On the other hand, basic characteristics of the enriched environment for the experimental group, designed in accordance with brain-based learning are given: (a) choosing texts to read according to one's interests; (b) a safe emotional environment, free of stress and threats has been provided; (c) brain gym activities have been provided in every session for five minutes; (d) breaks have been provided every 10 minutes; (e) natural relaxing music has been provided; (f) timely feedback has been provided; (g) lemon, cinnamon, and mild lavender that make the classroom smell pleasantly have been provided; (h) bottled water has been provided.

\section{Data Analysis}

The basic descriptive statistical parameters were calculated for all variables: the arithmetic mean (M) and standard deviation (SD). Normality of distribution was determined by the Kolmogorov-Smirnov test (KS test). The $\mathrm{Z}$ values of the KS test were not statistically significant for variables. The assumption of variance homogeneity was determined by the Levene test for equality of variance. The $\mathrm{F}$ value of the Levene test was not statistically significant for most variables, but was violated in reading speed post-tests. In order to determine the statistical significance of the difference between the means score for the experimental and control group in reading fluency, and reading comprehension on post-tests after eliminating the influence of the pretest, analyses of covariance (ANCOVAs) were used, whereas pre-tests were used as a covariate. In order to determine the statistical significance of the difference between the initial and final measurement of students' reading fluency and reading comprehension, t-tests for paired samples were applied. In addition to the ANCOVAs, independent samples t-test, and paired samples t-test, the authors also used the partial eta squared statistic ( $\eta 2$ ), which estimates effect size. For this statistic, values between 0.01 and 0.10 are considered a small effect size, values between 0.10 and 0.30 are regarded as a medium effect size, and those above 0.30 are considered a large effect size. The obtained test results were analysed using the SPSS 17.

\section{Results}

The purpose of this study was to investigate the effect of multisensory-based instruction combined with brain-compatible environment to increase reading fluency and reading comprehension of $4^{\text {th }}$ grade dyslexic students. The researchers followed the equivalent pre-/post-test designs for two groups. Therefore, the means, standard deviations, independent $t$-test, and paired samples t-test were used to analyse data.

Results of the independent samples t-test showed no significant differences between the two groups in reading speed $(\mathrm{t}=0.403, \mathrm{p}=0.659)$, accuracy $(\mathrm{t}=-0.315, \mathrm{p}=0.755)$ or reading comprehension $(\mathrm{t}=-0.437, \mathrm{p}=0.665)$ prior to training. Table 1 shows the mean and standard deviation of reading fluency, and reading comprehension according to groups. 
Soliman and Al-Madani: The Effects of Multisensory-Based Instruction Combined with Brain-Compatible ...

Table 1

Independent samples t-test data for the experimental and control group.

\begin{tabular}{lcccccccc}
\hline items & \multicolumn{9}{c}{ Experimental group } & \multicolumn{3}{c}{ Control group } & \multirow{2}{*}{$\mathrm{N}$} & \multirow{2}{*}{$\mathrm{p}$} \\
\cline { 2 - 7 } & $\mathrm{n}$ & $\mathrm{M}$ & $\mathrm{SD}$ & $\mathrm{n}$ & $\mathrm{M}$ & $\mathrm{SD}$ & & \\
\cline { 2 - 8 } Reading speed & 18 & 7.39 & 5.08 & 18 & 8.04 & 3.53 & -0.445 & 0.659 \\
Accuracy & 18 & 29.10 & 11.68 & 18 & 30.20 & 8.73 & -0.321 & 0.750 \\
Reading comprehension & 18 & 7.00 & 1.64 & 18 & 7.22 & 1.39 & -0.437 & 0.665 \\
\hline
\end{tabular}

The results were displayed based on the questions of the research. To determine if there is a statistically significant difference between the experimental and control group in reading fluency (reading accuracy and reading speed) and reading comprehension after eliminating the pre-test influence, ANCOVA was conducted. Table 2 shows the results.

Table 2

ANCOVA results of the difference between experimental and control groups in reading accuracy, reading speed and reading comprehension after eliminating influence of re-tests.

\begin{tabular}{llcccccc}
\hline Item & Group & E. Mean & Source & df & $\mathrm{F}$ & $\mathrm{p}$ & $\eta 2$ \\
\hline Reading accuracy & Exp. & 77.51 & Pre-test & 1 & 66.45 & 0.00 & \multirow{7}{*}{0.84} \\
& Con. & 31.71 & Group & 1 & 166.16 & 0.00 & 0.84 \\
& & & Error & 32 & & & \\
Reading speed & Exp. & 40.49 & Pre-tal & 36 & & & \\
& Con. & 9.35 & Group & 1 & 16.89 & 0.00 & \\
& & & Error & 32 & 53.12 & 0.00 & 0.62 \\
& & & Total & 36 & & & \\
Reading & Exp. & 9.02 & Pre-test & 1 & 43.98 & 0.00 & \\
comprehension & Con. & 7.53 & Group & 1 & 27.31 & 0.00 & 0.46 \\
& & & Error & 32 & & & \\
\hline
\end{tabular}

Table 2 shows that there was a statistically significant difference $(\mathrm{F}=166.16,53.12$, and $27.31 / \mathrm{p}=0.000,0.000$, and $0.000 / \eta 2=0.84,0.62,0.46$ ) between the reading fluency (reading accuracy and reading speed) and reading comprehension of the experimental group, and that of the control group on post-tests, in favour of the experimental group. This difference indicated that using multisensory-based instruction combined with brain-compatible environment may have had a positive effect on dyslexic students' reading fluency (reading speed and reading accuracy) and reading comprehension. The estimated marginal mean for the experimental group on the post-test of reading accuracy was 77.51, while that of the control group was 31.71; that of reading speed was 40.49 for the experimental group and 9.35 for the control group; that of reading comprehension was 9.02 for the experimental group and 7.53 for the control group.

To determine if there was a statistically significant difference between pre- and post-tests of reading fluency (reading accuracy and reading speed) and reading comprehension for the experimental group, a t-test for paired samples was conducted. Table 3 shows the results. 
Table 3

T-test results of the pre- and post-test for the experimental group.

\begin{tabular}{llrrccc}
\hline \multicolumn{1}{c}{ Measures } & Test & \multicolumn{1}{c}{ M } & \multicolumn{1}{c}{ SD } & T & Sig & n2 \\
\hline Reading speed & Pre- & 7.39 & 5.08 & -12.34 & 0.000 & 0.90 \\
& Post- & 42.10 & 12.54 & & & \\
Reading accuracy & Pre- & 29.10 & 11.68 & -20.01 & 0.000 & 0.96 \\
& Post- & 77.34 & 7.41 & & & \\
Reading & Pre- & 7.00 & 1.64 & -5.68 & 0.000 & 0.65 \\
comprehension & Post- & 9.00 & 0.76 & & & \\
\hline
\end{tabular}

Table 3 shows that there was a statistically significant difference $(t=-12.34,-20.01$, $-5.68 / \mathrm{p}=0.000,0.000,0.000 / \eta 2=0.90,0.96,0.65)$ between pre- and post-tests of reading fluency (reading speed and reading accuracy) and reading comprehension.

\section{Discussion}

The results of group comparisons of reading data clearly indicate that the intervention was successful in improving reading fluency. Students in the experimental group made significantly more progress in fluency than students in the control group, as measured by their performance in: (a) reading accuracy and (b) reading speed. The effect size values indicated a large effect size of the intervention.

Considering the learning environment, allowing students to choose reading passages they want increased their reading motivation. It appears that the brain-based environment components of multisensory reading strategies were evident among all experimental subjects. Students in the experimental group were therefore ready and enthusiastic about the activities, whereas control group students seemed indifferent about the tasks. It is evident from researchers' observations that experimental group students were happy to work in the classroom. Besides that, physical movement, tactile, olfactory, and gustatory activities performed in the experimental group provided a strong attraction for young children. For example, tracing words and letters while pronouncing the sounds and words kept students' hands busy, allowing for greater involvement time and focus on what they were doing during a particular session. Frequent writing on the sand tray and in the air allowed students to write with excitement and motivation. Movement breaks as a component of the brain-based environment improved students' concentration, listening skills, and attention span (Peck, Kehle, Bray, \& Theodore, 2005; Pellegrini \& Bohn, 2005; Powell, Gilchrist, \& Stabley, 2008).

In light of multisensory-based instruction, there may be several reasons for the outperformance of the experimental group. First, multisensory training builds many visual-auditory associations in learning grapheme-phoneme correspondences through kinaesthetic, olfactory, and gustatory activities. This develops attention span to details within letters or words, which helps with word retrieval from long-term memory (Nourbakhsh, Mansor, Baba, \& Madon 2013). Second, it provides more feedback from the instructors, and that feedback strengthens neural pathways in the brain (Hazoury 
et al., 2009; Uhry \& Clark, 2005). Third, as multiple senses and multiple learning pathways are activated during the learning process, this increases the probability that connections will form between the neural circuits in the brain that process information needed for efficient reading.

The design of the intervention program is in accordance with recommendations provided by Chard et al. (2002), NPR (2000), Therrien (2004), and Yang (2006), in their meta-analyses of fluency research which include the following important features: (a) incorporation of corrective feedback, (b) systematic progression to more difficult material as students master each level, and (c) repetitive practice.

This result is consistent with the results of research conducted by Chuen (2005), Duchock (1992), Foorman et al. (1997), Giess (2005), Heidari et al. (2012), Hook et al. (2001), Jeyasekaran (2015), Joshi et al. (2002), Kutrampos (1993), Litcher \& Roberge (1979), Mehrabi et al. (2014), Nourbakhsh (2014), Oakland et al. (1998), Stoner (1991) and Westrich-Bond (1993).

The results of group comparisons of reading comprehension clearly indicate that the intervention was successful in improving reading comprehension. Students in the experimental group made significantly more progress in comprehension than students in the control group, as measured by their performance on the reading comprehension test. The effect size value indicates a large effect size of the intervention.

The learning process can be more meaningful and effective when dyslexic students can apply all their senses. Each and every sense is a path in their brains. The more paths in the brain, the better the learning that happens (Subramaniam, Mallan, \& Mat, 2013). Mayer and Moreno (1998) found that learning outcomes are greater if the mixture of input is comprised of different modalities (e.g. visual and verbal), and that conjoint processing of the splits of information between modalities enhances students' recall and comprehension (Mousavi, Low, \& Sweller, 1995). Multiple studies conducted among a variety of students all concluded that there was a positive relationship between increased fluency and increased reading comprehension (Chard, Vaughn, \& Tyler, 2002; Kuhn \& Stahl, 2003, 2004; National Reading Panel, 2000; Rasinski \& Hoffman, 2003; Rasinski, Reutzel, Chard, \& Limon-Thompson, 2011; Therrien, 2004). Researchers have suggested that, when fluency is improved, students are able to focus more cognitive resources on understanding the material (LaBerge \& Samuels, 1974).

\section{Limitations and Future Directions}

The current study has several limitations. First, the sample utilised for this study may have not been representative of all dyslexic students because of the small size of the sample and gender (all participants were male), while the literature review of dyslexia indicates that the prevalence rates of dyslexia were $2: 1$ or 3:1. Future research should study larger sample sizes and incorporate male and female participants equally. Second, the current study measured only reading speed and accuracy to assess reading fluency. Both reading speed and accuracy are not the only components of reading 
fluency. Prosody (a meaningful expression) is the third component of reading fluency. Future research should study the effectiveness of the current intervention in all components of reading fluency. Third, the present study used only one measure for reading comprehension. Using multiple assessments of reading comprehension might have increased the accuracy of measuring RC. Future research should therefore use multiple assessments of reading comprehension. A fourth limitation is the lack of control over variables related to reading comprehension, such as verbal working memory and metacognitive skills. Future research should control the related variables of reading comprehension.

\section{Conclusion}

The research gives us an insight into the advantages of the combination of multisensory instruction and brain-based learning, concerning the acquisition of reading skills for students with dyslexia. Results show that the intervention was successful in improving the two sub-skills of reading fluency which include reading accuracy and reading speed with large effect size. The results also indicate that the intervention was successful in improving reading comprehension. Studentsparticipants were each diagnosed with a learning disability in reading and had a history of reading difficulties. Despite this history, the intervention implemented had positive effects on their reading performance, suggesting that these interventions may be a promising option when planning for students with dyslexia. Although the large effect size of reading data obtained was a result of the current intervention, greater effects may have resulted if the intervention had occurred for longer sessions and/or over a longer period of time.

\section{References}

Aaron, P., Joshi, R., \& Williams, K. (1999). Not all reading disabilities are alike. Journal of Learning Disabilities, 32, 120-137. https://doi.org/10.1177/002221949903200203

Al-Saeed, H. (2001). Reading disabilities: its etiology, reasons, and diagnosis. Education Journal, 31, 140, 178-187.

Al-Sartawi, Z., A. (2006). Assessment of reading disabilities. The International Conference on Learning Disabilities, 19-22 Nov. Riyadah, Saudi Arabia.

Benbow, C., P. (1986). Physiological correlates of extreme intellectual precocity. Neuropsychologia, 24, 719-725. https://doi.org/10.1016/0028-3932(86)90011-4

Bigler, E. D. (1990). Remediating nonverbal problems associated with learning disabilities. In P. T. Myers, \& D. D. Hammill (Eds.), Learning Disabilities (pp. 321-349). Austin, TX: Pro-Ed. 
Catts, H., Fey, M., Zhang, X., \& Tombin, J. (1999). Language basis of reading and reading disabilities: Evidence from a longitudinal investigation. Scientific Studies of Reading, 3, 331361. https://doi.org/10.1207/s1532799xssr0304 2

Caine, R. N., \& Caine, G. (1991). Making Connections: Teaching and the Human Brain. Alexandria, VA: Association for Supervision and Curriculum Development.

Caine, R. N., \& Caine, G., McClintic, C. L., \& Klimek, K. J. (2003). 12 Brain/Mind Learning Principles in Action. The Fieldbook to Making Connections, Teaching and the Human Brain. Thousand Oaks, CA: Corwin Press.

Chard, D. (1999). Word recognition instruction: Paving the road to successful reading. Intervention in School \& Clinic, 34(5), 271-277. https://doi.org/10.1177/ 105345129903400503

Chard, D. J., Vaughn, S., \& Tyler, B. J. (2002). A synthesis of research on effective interventions for building reading fluency with elementary school students with learning disabilities. Journal of Learning Disabilities, 35, 386-407. https://doi.org/10.1177/002221940203500 $\underline{50101}$

Chard, D., Katterlin-Geller, L., Baker, S., Doabler, C., \& Apichatabutra, C. (2009). Repeated reading interventions for students with learning disabilities: Status of the evidence. Exceptional Children, 75(3), 263-281. https://doi.org/10.1177/001440290907500301

Chuen, H. F. (2005). Incorporating Multi-Sensory Approach into Focused Word Recognition Method to Teach Children with Learning Difficulties in Hong Kong. Paper presented at the AARE Annual Conference (November/December). Parramatta, Malaysia.

Cohen, D. (2001). How a Child's Mind Develops. London: Routledge.

Compton, D., \& Carlisle, J. (1994). Speed of word recognition as a distinguishing characteristic of reading disabilities. Educational Psychology Review, 6(2), 115-140. https:// doi.org/10.1007/BF02208970

Cutting, L., \& Scarborough, H. (2006). Prediction of reading comprehension: Relative contributions of word recognition, language proficiency, and other cognitive skills can depend on how comprehension is measured. Scientific Studies of Reading, 10(3), 277-299. https://doi.org/10.1207/s1532799xssr1003 5

Duchock, Diedro, A. (1992). Training in Phonological Awareness: Comparing Auditory Blending to a Multi-Modal Approach (Dyslexia, Multimodal Approach). (Doctoral dissertation). Washington: Washington University.

Duff, F. J., \& Clarke, P. J. (2011). Practitioner review: Reading disorders: What are the effective interventions and how should they be implemented and evaluated? Journal of Child Psychology and Psychiatry, 52, 3-12. https://doi.org/10.1111/j.1469-7610.2010.02310.x

Ebner, F., \& Miller, S. (2003). Improving Primary Students' Reading Fluency. Chicago, IL: Unpublished Master's Thesis. (ERIC Document Reproduction Service Number ED479067).

Eden, G. F., \& Moats, L. (2002). The role of neuroscience in the remediation of students with dyslexia. Nature Neuroscience, 5, 1080-1084. https://doi.org/10.1038/nn946

Foorman, B. R., Francis, D. J., Winikates, D., Mehta, P., Schatschneider, C., \& Fletcher, J. M. (1997). Early interventions for children with learning disabilities. Scientific Studies in Reading, 1, 255-276. https://doi.org/10.1207/s1532799xssr0103 5 
Gabrieli, J. D. (2009). Dyslexia: A new synergy between education and cognitive neuroscience. Science, 325, 280-283. https://doi.org/10.1126/science.1171999

Giess, S. A. (2005). Effectiveness of a Multisensory, Orton-Gillingham Approach to Reading Intervention for High School Students with Reading Disability. (Doctoral dissertation). University of Florida.

Glgl, N. (1994). Dyslexia: A Diagnostic Remedial Study. (Doctoral dissertation). Kafr-Alshiekh: Tanta University.

Goldman-Rakic, P. S. (1992). Working Memory and the Mind. Scientific American, 268, 111115. https://doi.org/10.1038/scientificamerican0992-110

Good, R. H., \& Kaminski, R. A. (2002). Dynamic Indicators of Basic Early Literacy Skills (DIBLES). ( $\left.6^{\text {th }} \mathrm{ed}\right)$. Eugene, OR: University of Oregon.

Gorjian, B., Alipour, M., \& Saffarian, R. (2012). The Effect of Multisensory Techniques on Reading Comprehension among Pre-Intermediate EFL Learners: The Case of Gender. Advances in Asian Social Science, 1(2), 192-196.

Goswami, U. (2006). Neuroscience and education: From research to practice? Nature Reviews Neuroscience, 7, 406-413. https://doi.org/10.1038/nrn1907

Guthrie, J. T., Wigfield, A., Humenick, N. M., Perencevich, K. C., Taboada, A., \& Barbosa, P. (2006). Influences of stimulating tasks on reading motivation and comprehension. Journal of Educational Research, 99, 232-245. https://doi.org/10.3200/JOER.99.4.232-246

Hazoury, H., Oweini, A., \& Bahous, R. (2009). A Multisensory Approach to Teach Arabic Decoding to Students with Dyslexia. Learning Disabilities: A Contemporary Journal, 7(1), 1-20.

Heidari, T., Isfahani, A., Abedi, A., \& Bahramipour, M. (2012). The Comparison of the Effectiveness of Fernald and Davis Method on Reading Performance in the Dyslexic Students. Knowledge \& Research in Applied Psychology, 13(2), 34-42.

Hook, P., Macaruso, P., \& Jones, S. (2001). Efficacy of fast forward training on facilitating acquisition of reading skills by children with reading difficulties: A longitudinal study. Annals of Dyslexia, 51, 75-96. https://doi.org/10.1007/s11881-001-0006-1

Hudson, R. (2005). Reading fluency assessment and instruction: What, why, and how. Reading Teacher, 58(8), 702-714. https://doi.org/10.1598/RT.58.8.1

Hudson, R. F., High, L., \& Al Otaiba, S. (2007). Dyslexia and the brain: What does current research tell us? The Reading Teacher, 60, 506-515. https://doi.org/10.1598/RT.60.6.1

Jensen, E. (1996). Brain-Based Learning. Del Mar, CA: Turning Point Publishing.

Jeyasekaran, J. M. (2015). Effectiveness of visual auditory kinaesthetic tactile technique on reading level among dyslexic children at Helikx Open School and Learning Centre, Salem. International Journal of Medical Science and Public Health, 4(3), 315-318. https:// doi.org/10.5455/ijmsph.2015.0511201467

Joshi, R. M., Dahlgren, M., \& Boulware-Gooden, R. (2002). Teaching reading in an inner city school through a multisensory teaching approach. Annals of Dyslexia, 52, 229-242. https://doi.org/10.1007/s11881-002-0014-9

Kuhn, M. R., \& Stahl, S. A. (2003). Fluency: A review of developmental and remedial practices. Journal of Educational Psychology, 95, 3-21. https://doi.org/10.1037/0022-0663.95.1.3 
Kuhn, M. R., \& Stahl, S. A. (2004). Fluency: A review of developmental and remedial practices. In R. B. Ruddell, \& N. J. Unrau (Eds.), Theoretical Models and Processes of Reading, 5 th ed. (pp. 412-453). Newark, DE: International Reading Association.

Kutrampos, B. M. (1993). The Effect of Phonemic Training on Unskilled Readers: A SchoolBased Study (Remedial Reading, Dyslexia) Proquest Dissertation Abstracts International.

LaBerge, D., \& Samuels, S. J. (1974). Toward a theory of automatic information processing in reading. Cognitive Psychologist, 6, 293-323. https://doi.org/10.1016/0010-0285(74)90015-2

Leach, J., Scarborough, H., \& Rescorla, L. (2003). Late-emerging reading disabilities. Journal of Educational Psychology, 95, 211-224. https://doi.org/10.1037/0022-0663.95.2.211

Litcher, J. H., \& Roberge, L. P. (1979). First grade intervention for reading achievement of high risk children. Bulletin of the Orton Society, 24, 238-244. https://doi.org/10.1007/ BF02653745

Lynch, G., \& Baudry, M. (1984). The biochemistry of memory: A new and specific hypothesis. Science, 224, 1057-1063. https://doi.org/10.1126/science.6144182

Lyon, G., Shaywitz, S. E., \& Shaywitz, B. A. (2003). A definition of dyslexia. Annals of Dyslexia, 53(1), 1-14. https://doi.org/10.1007/s11881-003-0001-9

Mayer, R. E., \& Moreno, R. (1998). A split-attention effect in multimedia learning: Evidence for dual processing systems in working memory. Journal of Educational Psychology, 90(2), 312-320. https://doi.org/10.1037/0022-0663.90.2.312

McManus, I. C. (2002). Right Hand: Left Hand. London: Weidenfeld and Nicolson.

Mehrabi, A., Zarbakhsh, M., \& Rahmani, M. (2014). Effect of Multi-Sensory Teaching Method Using Sina Educational Instrument on Performance of Reading and Writing in Learning Disabled Children in Tonekabon City. Universal Journal of Management and Social Sciences, 4(7), 30-39.

Moats, L. C., \& Farrell, M. L. (2005). Multisensory structured language education. In J. R. Birsh (Ed.), Multisensory Teaching of Basic Language Skills (pp. 23-41). Baltimore, MD: Paul Brookes Publishing.

Mousavi, S. Y., Low, R., \& Sweller, J. (1995). Reducing cognitive load by mixing auditory and visual presentation modes. Journal of Educational Psychology, 87(2), 319-334. https://doi. org/10.1037/0022-0663.87.2.319

Myers, P. I., \& Hammill, D. D. (1990). Learning Disabilities. Austin, TX: Pro-Ed.

National Reading Panel. (2000). Report of the National Reading Panel: Teaching children to read. Bethesda, MD: National Institute of Child Health and Human Development.

Nourbakhsh, S., Mansor, M., Baba, M., \& Madon, Z. (2013). The Effects of Multisensory Method and Cognitive Skills Training on Perceptual Performance and Reading Ability among Dyslexic Students in Tehran-Iran. International Journal of Psychological Studies, 5(2), 92-99. https://doi.org/10.5539/ijps.v5n2p92

Nourbakhsh, S. (2014). The Efficacy of Multisensory Method and Cognitive Skills Training on Perceptual Performance and Reading Ability in Learning and Non-Learning Based Tests of Male Dyslexic Students in Tehran Iran. Asian Journal of Social Sciences \& Humanities, 3(1), 24-35.

Oakland, T., Black, J. L., Stanford, G., Nussbaum, N. L., \& Balise, R. R. (1998). An evaluation of the dyslexia training program: A multisensory method for promoting reading in 
students with reading disabilities. Journal of Learning Disabilities, 31, 140-148. https://doi. org/10.1177/002221949803100204

Parker, R., Hasbrouck, J. A., \& Tindal, G. (1992). Greater validity for oral reading fluency: Can miscues help? The Journal of Special Education, 25, 492-503. https://doi. org/10.1177/002246699202500406

Peck, H. L., Kehle, T. J., Bray, M. A., \& Theodore, L. A. (2005). Yoga as an intervention for children with attention problems. School Psychology Review, 34(3), 415-424.

Pellegrini, A. D., \& Bohn, C. M. (2005). The role of recess in children's cognitive performance and school adjustment. Educational Researcher, 35(1), 13-19. https://doi. org/10.3102/0013189X034001013

Peterson, R. L., \& Pennington, B. F. (2012). Developmental dyslexia. The Lancet, 379, 19972007. https://doi.org/10.1016/S0140-6736(12)60198-6

Pinnell, G. S., Pikulski, J. J., Wixson, K. K., Campbell, J., Gough, P., \& Beatty, A. S. (1995). Listening to Children Read Aloud. Washington, DC: Office of Educational Research and Improvement, U.S. Department of Education.

Pogorzelski, S., \& Wheldall, K. (2002). Do differences in phonological processing performance predict gains made by older low-progress following intensive literacy intervention? Educational Psychology, 22(4), 413-427. https://doi.org/10.1080/0144341022000003105

Powell, L., Gilchrist, M., \& Stapley, J. (2008). A journey of self-discovery: An intervention involving massage, yoga and relaxation for children with emotional and behavioural difficulties attending primary schools. European Journal of Special Needs Education, 23(4), 403-412. https://doi.org/10.1080/08856250802387398

Price, C. J., \& Mechelli, A. (2005). Reading and reading disturbance. Current Opinion in Neurobiology, 15, 231-238. https://doi.org/10.1016/j.conb.2005.03.003

Rasinski, T. V., \& Hoffman, J. V. (2003). Theory and research into practice: Oral reading in the school literacy curriculum. Reading Research Quarterly, 38, 510-522. https://doi. org/10.1598/RRQ.38.4.5

Rasinski, T. V., Reutzel, D. R., Chard, D., \& Limon-Thompson, S. (2011). Reading fluency. In M. L. Kamil, P. D. Pearson, E. B. Moje, \& P. P. Afflerbach (Eds.), Handbook of Reading Research. Vol. IV (pp. 286-319). New York, NY: Routledge.

Raven, J. C. (1984). Manual for the Colored Progressive Matrices. Revised. Windsore, UK: NFER Nelson.

Resch, F., Haffner, J., Parzer, P., Pfueller, U., Strehlow, U., \& Zerahn-Hartung, C. (1997). Testing the hypothesis of the relationships between laterality and ability according to Annett's right-shift theory: Findings in an epidemiological sample of young adults. British Journal of Psychology, 88, 621-626. https://doi.org/10.1111/j.2044-8295.1997.tb02661.x

Richards, M. (2000). Be a good detective: Solve the case of oral reading fluency. Reading Teacher, 53(4), 534-539.

Schlaggar, B. L., \& McCandliss, B. D. (2007). Development of neural systems for reading. Annual Review of Neuroscience, 30, 475-503. https://doi.org/10.1146/annurev. neuro.28.061604.135645

Shankweiler, D. (1999). Words to meanings. Scientific Studies of Reading, 3, 113-127. https:// doi.org/10.1207/s1532799xssr0302_2 
Soliman, A. (2005). Language Comprehension Disabilities. Cairo: Alfaker Alaraby publishing company.

Sousa, D. (1995). How the Brain Learns: A Classroom Teacher's Guide. Reston, VA: National Association of Secondary School Principals.

Stoner, J. (1991). Teaching at-risk students to read using specialized techniques in the regular classroom. Reading and Writing. An Interdisciplinary Journal, 3, 19-30. https://doi. org/10.1007/BF00554562

Subramaniam, V. Mallan, V. K., \& Mat, N. H. (2013). Multi-Senses Explication Activities Module for Dyslexic Children in Malaysia. Asian Social Science, 9(7), 241-267. https:// doi.org/10.5539/ass.v9n7p241

Swanson, H. (1999). Reading research for students with LD: A meta-analysis of intervention outcomes. Journal of Learning Disabilities, 32(6), 504-532. https://doi. org/10.1177/002221949903200605

Therrien, W. J. (2004). Fluency and comprehension gains as a result of repeated reading. Remedial and Special Education, 25, 252-261. https://doi.org/10.1177/07419325040250 040801

Torgesen, J. (2000). Individual differences in response to early interventions in reading: The lingering problem of treatment resisters. Learning Disabilities Research \& Practice, 15(1), 55-64. https://doi.org/10.1207/SLDRP1501_6

Torgesen, J. (2002). The prevention of reading difficulties. Journal of School Psychology, 40, 7-26. https://doi.org/10.1016/S0022-4405(01)00092-9

Torgesen, J. K., Wagner, R. K., Rashotte, C. A., Herron, J., \& Lindamood, P. (2010). Computerassisted instruction to prevent early reading difficulties in students at risk for dyslexia: Outcomes from two instructional approaches. Annals of Dyslexia, 60, 40-56. https://doi. org/10.1007/s11881-009-0032-y

Tunmer, W., \& Greaney, K. (2010). Defining dyslexia. Journal of Learning Disabilities, 43, 229 243. https://doi.org/10.1177/0022219409345009

Uhry, J., \& Clark, D. (2005). Dyslexia Theory and Practice of Instruction. Baltimore: York Press, Inc.

Wajuihian, S. O., \& Naidoo, K. S. (2012). Dyslexia: An overview. Optometry \& Vision Development, 43, 24-33.

Westrich-Bond, A. (1993). The Effect of Direct Instruction of a Synthetic Sequential Phonics Program on the Decoding Abilities of Elementary School Learning Disabled Students. (Doctoral dissertation). New Brunswick: The State University of New Jersey.

Wilmes, B., Harrington, L., Kohler-Evans, P., \& Sumpter, D. (2008). Coming to our senses: Incorporating brain research findings into classroom instruction. Education, 128(4), 659666.

Yang, J. (2006). Meta-Analysis of the Effects of Interventions to Increase Reading Fluency among Elementary School Students (Doctoral dissertation). Nashville, Tennessee: University of Vanderbilt. 


\section{Mohammad Said Soliman}

Special Education Department, Faculty of Arts and Education, Northern Border University

Air Port Street, 91431, Ar'ar city, Saudi Arabia

aiaamlomar@hotmail.com

Feras Mohammed AI-Madani

Curriculum and Instructions Department, Faculty of Arts and

Education, Northern Border University

Air Port Street, 91431, Ar'ar city, Saudi Arabia

f76m21@gmail.com 


\section{Učinci poučavanja utemeljenog na višeosjetilnosti i tehnikama okoline prilagođene mozgu na tečnost čitanja i razumijevanje prilikom čitanja disleksičnih učenika četvrtih razreda}

\section{Sažetak}

Glavni je cilj rada istražiti utjecaj poučavanja utemeljenog na višeosjetilnosti $i$ tehnikama okoline prilagođene radu mozga na tečnost čitanja i razumijevanje prilikom čitanja disleksičnih arapskih učenika četvrtih razreda osnovne škole. U istraživanju je sudjelovalo 38 učenika s disleksijom, podijeljenih u dvije skupine: jednu s 18 učenika u kojoj je provedena intervencija (eksperimentalna skupina) $i$ jednu s 18 učenika u kojoj nije provedena intervencija (kontrolna skupina). Tečnost čitanja i razumijevanje prilikom čitanju u pred-i posttestiranjima mjereni su testom tečnosti čitanja i testom razumijevanja prilikom čitanja. Poučavanje je održano u eksperimentalnoj skupini - među učenicima s disleksijom - tijekom 70 sesija. Rezultati su pokazali statistički značajne razlike u posttestiranjima tečnosti čitanja i razumijevanja prilikom čitanja između kontrolne i eksperimentalne skupine, $u$ korist eksperimentalne skupine, kao i statistički značajne razlike u rezultatima koje su učenici eksperimentalne skupine ostvarili na pred-i posttestiranjima, u korist posttestiranja tečnosti čitanja i razumijevanja prilikom čitanja. Rasprava nudi smjernice za buduća istraživanja intervencija na polju čitanja među učenicima s disleksijom.

Ključne riječi: disleksija; razumijevanje prilikom čitanja; tečnost čitanja; učenje prilagođeno mozgu; višeosjetilni pristup.

\section{Uvod}

Učinkovito čitanje akademska je vještina koja ima važnu ulogu u školskom uspjehu. Sposobnost učinkovitog i tečnog čitanja jedan je od preduvjeta profesionalnog uspjeha. Budućnost učenika stoga uvelike ovisi o njihovoj sposobnosti da dobro 
čitaju i uspješno savladaju vještinu učinkovitog čitanja. U tom smislu poučavanje čitanja predstavlja jednu od najvažnijih zadaća javnoga obrazovanja, osobito u ranim stadijima učenja. Riječ je o jednoj od najvažnijih vještina koju bi učenici trebali savladati u školi. Swanson (1999) naglašava da je čitanje nužno za većinu akademskih disciplina i kompatibilno s većinom školskih aktivnosti; učenje i ovladavanje vještinom čitanja u tom je smislu od velike važnosti. Zidan Al-Sartawi (2006) napominje da se čitanje smatra najvažnijom vještinom koja se uči u školi. Prema Suleimanu AlSayedu (2005) čitanje je važan preduvjet uspjeha u školi (djeca s poteškoćama u čitanju uglavnom ostvaruju slabije rezultate u školi). Chard i sur. (2009) smatraju da je sposobnost učinkovitog čitanja najvažnija vještina koja će odrediti uspjeh učenika u školi. Neuspjeh u svladavanju vještine čitanja, posebno u ranim fazama učenja, rezultira negativnim utjecajima koji se - ako ih se ne tretira na primjeren način protežu na sve aspekte kognitivnog, emocionalnog i bihevioralnog razvoja učenika. Da bi se učenicima pružila pomoć, svrstava ih se u odgovarajuće skupine utemeljene na razini čitanja, koje su u skladu s njihovim sposobnostima.

Službeni izvještaji bilježe značajan porast broja učenika s poremećajima čitanja. Najčešći poremećaj čitanja, posebno među učenicima osnovnih škola, jest disleksija. Poremećaji čitanja utvrđeni su među oko $80 \%$ populacije koja pati od poremećaja učenja (Hudson i sur., 2007; Lyon i sur., 2003). Među spomenutom je populacijom najučestaliji poremećaj učenja disleksija (Torgesen i sur. 2010; Wajuihian i Naidoo, 2012). Riječ je o neurološkom poremećaju obilježenom disfunkcijom jezične mreže u lijevoj polutki mozga (Eden i Moats, 2002; Gabrieli, 2009; Goswami, 2006; Peterson i Pennington, 2012; Price i Mechelli, 2005; Schlaggar i McCandliss, 2007), koja dovodi do osobitih poteškoća u svladavanju učinkovitog čitanja, a javlja se usprkos normalnoj inteligenciji, izostanku očitih osjetilnih poremećaja i primjerenom poučavanju (Lyon i sur., 2003). Među učenicima osnovnih škola disleksija se manifestira kao poremećaj jedne ili više vještina takozvane niže razine (identifikacija riječi i fonološka svijest ili obrada), kao i vještina takozvane više razine, kao što su razumijevanje prilikom čitanja, koje je krajnji rezultat procesa čitanja. Da bi učenici savladali vještinu razumijevanja prilikom čitanja i upoznali se s vokabularom, najprije moraju savladati vještine niže razine, $t$. vještinu identifikacije koja bi trebala djelovati automatski i ispravno. Nedostatak te vještine jedan je od glavnih uzroka slabog razumijevanja prilikom čitanja, o čemu svjedoče studije koje između ostalih potpisuju Aaron i sur. (1999), Catts i sur. (1999), Cutting i Scarborough (2006), Leach i sur. (2003), Shankweiler (1999) i Torgesen (2002).

Posljedica je toga da mnoge studije pokazuju kako je u programima za unapređivanje vještine razumijevanja razvoj niskorazinskih vještina identifikacije preduvjet za unapređivanje razumijevanja prilikom čitanja među učenicima s disleksijom. Radi se o ključnom preduvjetu, osobito u slučaju učenika s jasno izraženim poteškoćama s identifikacijom riječi. Osim toga, što prije započnemo s liječenjem, možemo očekivati bolje rezultate (Chard, 1999; Pogorzelski i Wheldall, 2002; Torgesen, 2000). 
Literatura o poremećajima čitanja ukazuje na značajnu i odlučujuću vještinu vezanu uz disleksiju, koju bi trebalo uzeti u obzirom prilikom izrade nužnih programa liječenja. Međutim, ta vještina - tečnost čitanja - često se zanemaruje prilikom učenja čitanja ili liječenja poremećaja čitanja. Dobar bi čitatelj trebao čitati glatko i tečno, te brzo prepoznavati riječi bez zadržavanja na njima dulje vrijeme. Compton i Carlisle (1994) navode da brojne teorije razvoja učinkovitog čitanja ističu važnost poučavanja pravilnog, tečnog i glatkog čitanja riječi. Precizna identifikacija riječi čitatelju omogućava razumijevanje ideja izraženih u tekstu (za to je, pak, nužno da se spomenuti proces odvija dovoljno brzo), što, pak, dovodi do razumijevanja značenja teksta. Isto u svojim studijama naglašavaju i Ebner i Miller (2003), Hudson (2005) i Richards (2000). Prema Nacionalnoj procjeni napretka u obrazovanju (National Assessment of Educational Progress, skrać. NAEP), 44\% učenika četvrtih razreda ima poteškoće s tečnim čitanjem tekstova namijenjenih njihovoj razini. Prijašnje je istraživanje pokazalo da učenici koji imaju poteškoća s tečnošću čitanja imaju poteškoća i s razumijevanjem prilikom čitanja (Pinnell i sur., 1995).

Na temelju svega navedenog jasno je da pri ispravljanju poremećaja čitanja u obzir valja uzeti niz čimbenika: povećavanje brzine, točnosti i tečnosti čitanja disleksičnih učenika, kako bi se u njima razvio osjećaj postignuća koji će poslije utjecati na razvoj razumijevanja prilikom čitanja.

Jasno je, dakle, da disleksičnim učenicima najviše poteškoća stvaraju identifikacija riječi i tečnost. Obje komponente utječu na njihovo razumijevanje teksta koji čitaju jer sporo identificiraju riječi. Budući da je većina njihove pažnje usredotočena upravo na razinu identifikacije riječi, ne uspijevaju rekonstruirati značenje teksta. Postavlja se pitanje o tome koja je najučinkovitija strategija unapređivanja tečnosti čitanja i razumijevanja prilikom čitanja, posebno u kontekstu brojnih poznatih strategija koje potiču tečnost čitanja i pomažu prilikom unapređivanja vještine čitanja disleksične djece (Duff i Clarke, 2011). Mnoge od tih strategija uključuju neki oblik intervencije čiji je cilj unaprijediti sposobnosti učenika na fonološkoj razini i razini riječi. Neki istraživači upozoravaju na to da fokusiranje na spomenutu vještinu „zapravo može pridonijeti neuspjehu u čitanju, jer pažnju djeteta odvlači od produktivnijih strategija “ (Tunmer i Greaney, 2010, str. 234). U liječenju disleksije koriste se brojne i raznolike metode i strategije. Jedna od njih do sada nije privukla odgovarajuću pozornost arapskih i međunarodnih studija o terapiji i poučavanju: riječ je o višeosjetilnoj strategiji poučavanja. U kontekstu poučavanja čitanja pojam višeosjetilnosti odnosi se na tehnike za čitatelje početnike ili one koji se susreću s poteškoćama u čitanju, a obuhvaćaju vizualne, auditivne, taktilne i motoričke komponente integrirane $\mathrm{u}$ program s pažljivo osmišljenim slijedom, utemeljenim na strukturi jezika i znanju o jeziku (Moats i Farrell, 2005). Najučinkovitiji proces učenja aktivira sva učenikova osjetila, što također pridonosi boljem usvajanju i pamćenju novih znanja (Cohen, 2001). Kognitivna neuroznanost nudi teorijsku podršku za primjenu višeosjetilnog poučavanja, koje prati način na koji pamćenje djeluje: 
U procesu učenja, jednostavnije je integrirati višestruke izvore informacija kada se radi o fizički, auditivno i vizualno integriranim materijalima, nego kad se informacije predstavljaju odvojeno u različitim modalitetima (Mousavi i sur., 1995, str. 319).

Brojne empirijske studije istražile su učinak višeosjetilnog poučavanja na razvoj vještina čitanja disleksičnih učenika osnovne škole (Chuen, 2005; Foorman i sur. 1997; Heidari i sur., 2012; Hook i sur., 2001; Jeyasekaran, 2015; Joshi i sur., 2002; Kutrampos, 1993; Mehrabi i sur., 2014; Nourbakhsh, 2014; Oakland i sur., 1998; itd.).

$S$ druge strane, učenje utemeljeno na mozgu (brain-based learning, skrać. BBL) novi je trend u obrazovanju. BBL se temelji na rezultatima neuroloških istraživanja, primijenjenima u obrazovnom kontekstu. Pristup je osmišljen na način koji ga čini kompatibilnim sa strukturom, sklonostima i optimalnom funkcijom ljudskoga mozga, kako bi se osigurala učinkovitost individualnog procesa učenja (Caine i Caine, 1991, 2003; Jensen, 1996; Sousa, 1995). Pretpostavku da se učenjem stvaraju neuroanatomske promjene koje mogu ispraviti neurološke disfunkcije koje su u osnovi disleksije stvaranjem novih sinapsi, potvrdila su brojna istraživanja provedena proteklih desetljeća (Bigler, 1990; Goldman-Rakic, 1992; Lynch i Baudry, 1984; Myers i Hammill, 1990). Na temelju spomenute hipoteze te uzimajući u obzir faktore koji utječu na proces učenja kao što su okolina, emocije, psihologija i polovine mozga, zaključujemo da bi BBL pristup mogao biti osobito primjeren za učenike s disleksijom. U kontekstu učenja utemeljenog na mozgu, kretanje, pauze, obogaćen okoliš lišen stresa, straha i napetosti, pozitivne emocije, redovne povratne informacije, boce vode, ugodni osmjesi i prirodna opuštajuća glazba predstavljaju važne elemente u procesu proizvodnje novih sinapsi koje sudjeluju u stvaranju novih neuroloških mreža (Moats i Farrell, 2005). Time je potvrđena pretpostavka o korištenju BBL strategijom sa svrhom stvaranja optimalnog okoliša za učenje koji je prilagođen mozgovima učenika s disleksijom.

U ovom se radu stoga ispituje učinkovitost primjene višeosjetilne strategije poučavanja kombinirane s okolinom prilagođenom radu mozga, s ciljem razvoja tečnosti čitanja i razumijevanja pri čitanju među disleksičnim učenicima četvrtih razreda.

\section{Izjava o istraživanju}

Službeni statistički podaci pokazuju da je broj učenika s poremećajima čitanja u osnovnim školama u porastu, što je razlog za zabrinutost. Statistički podaci pokazuju da je spomenuto povećanje veće u društvima u razvoju kao što je Saudijska Arabija, osobito s obzirom na prenapučene razrede $u$ školama i učitelje kojima nedostaju odgovarajuće vještine i sposobnosti.

Al-Saeed (2001) i Al-Sartawi (2006) napominju da učenici s poremećajima čitanja čine 10 - 15\% ukupnog broja školske djece. Soliman (2005) navodi procjene prema kojima stopa porasta broja učenika osnovnih škola s poteškoćama u čitanju iznosi 
$20 \%$, što je razlog za zabrinutost. Spomenute će brojke vjerojatno nastaviti rasti zbog nedovoljne brige i mogućnosti pružanja pomoći tim učenicima u ranim stadijima poremećaja (posebno u nižim razredima). S druge strane, relevantna literatura upućuje na manjak niza podvještina koji dovodi do pada razine tečnosti čitanja i razumijevanja prilikom čitanja. Chard i sur. (2009) učinkovito čitanje opisuju kao složen proces koji obuhvaća identifikaciju (ili dekodiranje) riječi i razumijevanje.

Brojne su terapeutske strategije koje se koriste s ciljem rješavanja spomenutog problema među učenicima s poremećajima čitanja, primjerice opetovano čitanje, čitateljsko kazalište i zborsko čitanje. U većini istraživanja nisu se koristili testovi daljnjeg praćenja kojima bi se utvrdili dugoročni učinci spomenutih strategija. Autori pretpostavljaju da bi rezultati testova daljnjeg praćenja mogli otkriti smanjenje tečnosti čitanja i razumijevanja pri čitanju. To bi se, pak, moglo pripisati činjenici da se spomenute strategije ne temelje na integriranom modelu koji u obzir uzima psihološke, fiziološke, kognitivne i društvene aspekte učenja. Istraživači su stoga nastojali pronaći rješenja za spomenute probleme i tragali za najučinkovitijim strategijama kojima bi se mogla razviti tečnost čitanja. U istraživanjima provedenima na tom području, jedna važna i osnovna tehnika pokazala se učinkovitom u uvećanju tečnosti čitanja na razini riječi među učenicima s poremećajima čitanja: poučavanje višeosjetilnom strategijom. Međutim, spomenuta strategija nije privukla odgovarajuću pozornost arapskih istraživača. Brojna empirijska istraživanja ispitivala su učinak višeosjetilnog poučavanja na razvoj vještina čitanja među disleksičnim učenicima.

Jeyasekaran (2015) ispituje učinak vizualne, auditivne, kinestetičke i taktilne (visual, auditory, kinaesthetic and tactile, skrać. VAKT) tehnike na razinu čitanja disleksične djece u školi i Centru za učenje Helikx u Indiji. 30 ispitanika odabrano je primjenom tehnike namjernih uzoraka. Istraživanje je provedeno uz pomoć intervencije VAKT tehnikom i Schonellovim testom ocjenjivanja čitanja riječi. Intervencijska VAKT tehnika koristila se među disleksičnom djecom tokom 30 uzastopnih dana i bila je popraćena procjenom razine nakon čitanja. Rezultati pokazuju porast srednje vrijednosti razine čitanja nakon intervencije od $12 \%$. Nadalje, rezultati ukazuju na značajnu statističku razliku prije i nakon intervencije $(\mathrm{p}<0,05)$. To dokazuje da VAKT tehnika vrlo učinkovito unaprjeđuje razinu čitanja disleksične djece.

Nourbakhsh (2014) ispituje učinke višeosjetilne metode i intervencije treningom kognitivnih vještina na sposobnost čitanja disleksičnih učenika u Iranu. 60 učenika trećih razreda koji su sudjelovali u ovome istraživanju podijeljeno je u tri eksperimentalne skupine: po 20 disleksičnih učenika činilo je prvu (E1) i drugu eksperimentalnu skupinu (E2), te kontrolnu skupinu (C). U istraživanju su korištene intervencije u trajanju od 16 tjedana, testovi čitanja i disleksije, Bender vizualnomotorički geštalt test $i$ Rorschachov test. Rezultati testiranja prije i nakon intervencije pokazali su napredak u obje skupine (E1 i E2). Nadalje, testovi čitanja i disleksije zabilježili su značajan napredak u obje skupine na polju percepcije.

Mehrabi i sur. (2014) ispituju utjecaj višeosjetilne metode poučavanja, primjenom obrazovnog instrumenta Sina za mjerenje razine čitanja i pisanja među djecom s 
poremećajima učenja u gradu Tonekabonu (Iran). Uzorak istraživanja obuhvaća 30 nasumično odabrane djece s poremećajima čitanja i pisanja. Ispitanici su nasumce podijeljeni u dvije skupine: eksperimentalnu i kontrolnu. Za prikupljanje podataka koristili su se testovi čitanja i disleksije (NAMA), pisanja, kao i Wechslerov test inteligencije za djecu (WISC-R). Eksperimentalna skupina sudjelovala je u 13 tjednih sesija strukturiranog treninga u trajanju od 45 minuta. Rezultati su pokazali da Sina višeosjetilna metoda poučavanja unapređuje sposobnost čitanja i pisanja među djecom s poremećajima učenja.

Gorjian i sur. (2012) istražili su utjecaj višeosjetilnih tehnika na razumijevanje pri čitanju (reading comprehension, skrać. RC) s pomoću višeosjetilnih (vizualnih, taktilnih, auditivnih, motoričkih) modaliteta. 60 sudionika odabrano je na temelju njihovih homogenih rezultata na testu razumijevanja pri čitanju. U eksperimentalnoj se skupini poučavanje razumijevanja pri čitanju odvijalo s pomoću višeosjetilnih tehnika, a u kontrolnoj je skupini primijenjen placebo. Podatci su prikupljani putem testiranja prije i nakon 12 sesija. Rezultati otkrivaju značajne razlike među dvjema skupinama; eksperimentalna je skupina ostvarila bolje rezultate na testovima provođenim nakon sesija u odnosu na kontrolnu skupinu.

Heidari i sur. (2012) usporedili su učinkovitosti Davisove i Fernald metode na uspješnost čitanja disleksičnih učenika trećih razreda osnovnih škola. Statistička je populacija obuhvaćala disleksičnu djecu koja su u prosincu 2011. godine upućena u kliniku Shenakht i Alefba Zendegi u gradu Isfahanu. Uzorak istraživanja odabran je metodom prigodnoga uzorka. Među djecom upućenom u spomenutu kliniku, 45 ih je odabrano kao konačan uzorak, a zatim nasumično podijeljeno u dvije eksperimentalne (15 učenika u eksperimentalnoj skupini u kojoj se primjenjuje Fernald metoda, 15 učenika u eksperimentalnoj skupini u kojoj se primjenjuje Davisova metoda) i jednu kontrolnu skupinu (15 učenika).S ciljem procjene koristili su se test čitanja (Reading Test, skrać. RT) i Wechslerov test inteligencije za djecu (WISC-IV). Intervencije su provođene u dvije eksperimentalne skupine, i to u obliku deset 30-minutnih sesija u skupini u kojoj je primijenjena Fernald metoda, zatim šesnaest 30-minutnih sesija u skupini u kojoj je primijenjena Davisova metoda. Software SPSS-15 koristio se za bilježenje rezultata nakon testiranja i analizu podataka. Rezultati analize otkrivaju značajnu razliku između srednjih vrijednosti na testovima čitanja dviju eksperimentalnih skupina i na završnom testiranju u kontrolnoj skupini, $\mathrm{u}$ korist eksperimentalne skupine u kojoj je primjenjivana Fernald metoda.

Chuen (2005) istražuje učinkovitost inkorporiranja višeosjetilnih i tehnika učenja potpomognutih računalom $u$ „metodu fokusiranog prepoznavanja riječi“, s ciljem poučavanja točnosti u čitanju i pisanju na kineskom jeziku među djecom s disleksijom. U istraživanju je sudjelovalo šest učenika drugih razreda osnovnih škola koji su istodobno sudjelovali u intenzivnom programu ponovljenog poučavanja (Intensive Remedial Teaching Programme, skrać. IRTP). Trening se sastojao od deset sesija, održanih u razdoblju od siječnja 2003. do ožujka 2003. godine. Rezultati testiranja 
prije i poslije sesija pokazuju da je točnost čitanja i pisanja kineskih znakova među sudionicima znatno unaprijeđena.

S druge strane, posljednjih se desetljeća javlja pretpostavka prema kojoj proces učenja dovodi do stvaranja morfološko-neuroloških promjena koje mogu ispraviti neurološke poremećaje koji uzrokuju disleksiju formiranjem novih sinaptičkih točaka. Spomenuta je hipoteza dokazana (Bigler, 1990; Goldman-Rakic, 1992; Lynch i Baudry, 1984; Myers i Hammill, 1990). Njome se pokazuje učinkovitost korištenja strategijama učenja prilagođenih radu mozga s ciljem stvaranja optimalne okoline za učenje koja odgovara mozgovima učenika s disleksijom. Empirijska istraživanja koja se bave učinkovitošću učenja prilagođenog mozgu u kontekstu traganja za učinkovitim intervencijama za učenike s disleksijom su ograničena.

Ovaj će rad ponuditi odgovor na sljedeće pitanje: kakav je učinak programa utemeljen na višeosjetilnom pristupu kombiniranom s okolinom prilagođenom radu mozga na povećanje tečnosti čitanja i razumijevanja pri čitanju među disleksičnim učenicima četvrtih razreda? Ovdje valja izdvojiti i dva potpitanja:

1 - Postoje li statistički značajne razlike među srednjim vrijednostima rezultata eksperimentalne i kontrolne skupine učenika na završnim testovima točnosti, brzine i razumijevanja pri čitanju, nakon eliminacije utjecaja prije testiranja?

2 - Postoje li statistički značajne razlike među srednjim vrijednostima prosječnih rezultata eksperimentalne skupine na pred-i posttestiranjima točnosti, brzine i razumijevanja priliko čitanja?

\section{Važnost istraživanja}

Istraživanje se bavi disleksičnim učenicima četvrtih razreda osnovnih škola. Od učenika se očekuje da čitaju učinkovito, u skladu s dosegnutim stadijem obrazovanja, nakon kojega ih očekuju brojna raznolika i napredna obrazovna iskustva. Rad je smješten $\mathrm{u}$ red studija koje istražuju spomenuti problem u ovoj kritičnoj fazi u obrazovnom životu učenika. (Ne)mogućnost rješavanja toga problema u velikoj mjeri određuje obrazovnu i radnu budućnost učenika. Rad se bavi zanemarivanom vještinom unutar poučavanja čitanja: vještinom tečnosti čitanja. Općenito govoreći, prilikom poučavanja čitanja učitelji spomenutu vještinu ne uzimaju u obzir, a koliko je autorima rada poznato ona nije niti adekvatno istražena. Ovaj rad stoga nastoji skrenuti pozornost istraživača i učitelja na tu zanemarenu vještinu čitanja te potaknuti njezino proučavanje i istraživanje, posebno $u$ arapskom kontekstu. Rad poziva na istraživanje spomenute strategije čitanja $u$ arapskom kontekstu te nastoji ustvrditi njezinu učinkovitost u unapređivanju tečnosti čitanja disleksičnih učenika. Rad nastoji skrenuti pozornost istraživača na tu strategiju kako bi se uzela u obzir prilikom osmišljavanja eksperimentalnih programa čiji je cilj unaprijediti slabe vještine čitanja ili samo poučavanje čitanja. Rezultati istraživanja imaju moguću primjenu u polju obrazovanja i mogli bi biti korisni svima zainteresiranima za područje poremećaja čitanja, napose u slučajevima sličnima onima obuhvaćenima istraživanjem. 


\section{Metoda}

\section{Sudionici}

Učenici četvrtih razreda osnovnih škola s disleksijom koji su upućeni u Centar za specifične poremećaje učenja pohađaju četiri škole obuhvaćene ovim istraživanjem. Sudionici su odabrani među učenicima koje su njihove osnovne škole uputile u javni Centar za specifične poremećaje učenja. Dijagnostički standardi korišteni u Centru u skladu su s Dijagnostičkim i statističkim priručnikom za duševne poremećaje (4. izdanje, DSM-IV) za disleksiju. U istraživanju su sudjelovala disleksična djeca koja su zadovoljavala sljedeće kriterije: (1) nisu prije liječena zbog disleksije; (2) zadovoljavaju DSM-IV kriterije za disleksiju, uključujući: (a) poteškoće s točnošću i/ili tečnošću prepoznavanja riječi; (b) manjkavu sposobnost dekodiranja riječi; (c) poteškoće $s$ brzinom čitanja; (d) slabu prozodiju i (e) poteškoće s razumijevanjem pri čitanju; (3) ostvarila su rezultat od 80 ili više na testu inteligencije; (4) ostvarila su prosječni T-rezultat od 70 ili više na četiri podskale na testu za otkrivanje disleksije; (5) nemaju poremećaje neurološkog razvoja, sluha, vida ili bilo koje druge značajne poremećaje; (6) govore arapski kao materinski jezik i dešnjaci su, što je važno zbog utjecaja dominantne ruke na kognitivne sposobnosti (Benbow, 1986; McManus, 2002; Resch i sur., 1997). Od ukupnog broja djece u spomenutom uzorku njih 36 zadovoljilo je nabrojane kriterije (prosječna dob $=10,21, \mathrm{SD}=1,024$ ). Odabrani sudionici podijeljeni su u dvije skupine s po 18 muških učenika: eksperimentalnu (prosječna dob $=10,34$, $\mathrm{SD}=1,329$ ) i kontrolnu skupinu (prosječna dob $=9,85, \mathrm{SD}=0,476$ ).

\section{Mjere}

Test za dijagnosticiranje disleksije (Dyslexia Diagnostic Test, skrać. DDT) standardizirala je Nassra Glgl sa Sveučilišta Tanta (2008). Radi se o testu za dijagnosticiranje sposobnosti čitanja učenika s disleksijom koji se primjenjuje pojedinačno ili u skupinama. Test se sastoji od 80 jedinica razdijeljenih u četiri skupine kojima se ocjenjuje sposobnost čitanja, uključujući prepoznavanje riječi, razumijevanje riječi, razumijevanje rečenica i razumijevanje odlomaka. Svaki odgovor u testu vrijedi jedan bod. Unutarnja konzistentnost testa (određena uz pomoć Cronbachove alfe) iznosi 0,72 .

Ravenove progresivne matrice u boji međunarodno su priznate kao kulturno pravedan test neverbalne inteligencije mlađe djece (Raven i sur., 1990). Radi se o standardiziranom testu koji se sastoji od 36 jedinica podijeljenih u tri seta: A, B i $\mathrm{AB}$, pri čemu se svaki set sastoji od 12 jedinica. Svaka jedinica geometrijski je oblik prikazan na obojenoj pozadini. Dio oblika nedostaje i od sudionika se traži da ga prepoznaju među šest ponuđenih opcija. Problemi su isprva lagani, no postaju teži kako test odmiče.

Test tečnosti čitanja. Istraživači su osmislili taj test u suodnosu s testovima opisanima u teorijskoj literaturi i srodnim istraživanjima, kao što je test koji su opisali Good i Kaminski (2002). Mjereni su kombinirani rezultati dvaju usmenih testova čitanja: 
brzine čitanja teksta i točnosti čitanja teksta. Rezultat brzine čitanja teksta dobiva se dijeljenjem broja točno pročitanih riječi ukupnim vremenom potrebnim za čitanje čitavog odlomka izraženim u sekundama, te množenjem rezultata sa 60 (Parker i sur., 1992). Rezultat točnosti čitanja teksta dobiva se dijeljenjem broja točno pročitanih riječi ukupnim brojem pročitanih riječi, te množenjem tog rezultata sa 100 (Parker i sur., 1992). Učenici su morali naglas pročitati primjeren tekst od 190 riječi, pisan veličinom slova 16. S ciljem određivanja ispravnosti sadržaja testa, primijenjena su mišljenja devetoro stručnjaka s područja kurikula i poučavanja, kao i posebnog obrazovanja. Unutarnja konzistentnost testa, mjerena Cronbachovim alfa koeficijentom, iznosila je 0,86.

Test razumijevanja pri čitanju. Namijenjen mjerenju razumijevanja pri čitanju, test obuhvaća čitanje pripovjednog teksta, popraćenog pitanjima s više ponuđenih odgovora. Od učenika se očekuje da u sebi pročitaju tekst i potom odgovore na deset pitanja s više ponuđenih odgovora. Pri izradi testa istraživač u obzir uzima sljedeće razine razumijevanja pri čitanju: doslovno razumijevanje, interpretativno razumijevanje, razumijevanje na razini promišljanja i razumijevanje na razini ocjenjivanja. S ciljem procjene ispravnosti sadržaja testa, primijenjena su mišljenja devet stručnjaka u područjima kurikula i poučavanja, kao i posebnog obrazovanja. Unutarnja konzistentnost testa razumijevanja pri čitanju, izračunata s pomoću Cronbachova alfa koeficijenta, iznosi 0,74.

\section{Postupak}

Sudionici su podijeljeni u dvije skupine: eksperimentalnu (18 učenika) i kontrolnu (18 učenika). Testovi tečnosti čitanja i razumijevanja pri čitanju primijenjeni su u obje skupine kao inicijalni testovi. Fizički je okoliš prilagođen kako bi bio što kompatibilniji s principima učenja koji su usklađeni s ljudskim mozgom. U eksperimentalnoj je skupini primijenjena intervencija, a u kontrolnoj skupini tradicionalna metoda. Testovi tečnosti čitanja i razumijevanja pri čitanju u obje su skupine primijenjeni kao završni testovi.

\section{Intervencija}

Projekt je provođen 14 tjedana u dvije skupine: eksperimentalnoj i kontrolnoj. Poučavanje utemeljeno na višeosjetilnosti slijedilo je ovdje opisane korake tijekom 70 sesija. Intervencija je provođena u obliku poučavanja utemeljenog na višeosjetilnosti, koje pri čitanju angažira vizualna, auditivna, taktilna, kinestetička, olfaktivna i gustativna osjetila. Za učenike s poteškoćama u čitanju, učiti kako učiti neprestan je proces. Prvi je autor provodio višeosjetilnu intervenciju u eksperimentalnoj skupini tijekom 60-minutne sesije. Prije svake sesije istraživač je provodio neformalnu procjenu osjetila učenika. Strategija se sastojala od toga da učenici najprije odaberu jedan odlomak iz skupine prije određenih odlomaka. Njihovi odabiri predstavljeni su kao način da ih se motivira da prilikom čitanja daju sve od sebe (Guthrie i sur., 
2006). Nakon odabira odlomka, učenici su (u skupinama od tri) sudjelovali u sljedećim vježbama:

Primijenjeno je ponavljanje grafema i ponavljanje fonema u svakoj riječi u odabranome odlomku. Istraživač se koristio eksplicitnim poučavanjem kako bi objasnio vezu između fonema i grafema. Izravno poučavanje veza između fonema i grafema unapređuje sposobnosti dekodiranja, naročito među disleksičnim učenicima (Uhry i Clark, 2005). Istraživač se koristio eksplicitnim pristupom poučavanju zbog fonoloških nedostataka disleksičnih učenika.

Vizualna i auditivna vježba: istraživač pokazuje svaku riječ iz odabranog odlomka na kartici i glasno je izgovara. Učenici ponavljaju riječ pet puta.

Kombinirana taktilna, kinestetička, auditivna i vizualna vježba: učenici oblikuju svaku riječ iz odabranog odlomka koristeći se magnetskim slovima. Riječ prate kažiprstom i pritom je glasno izgovaraju. Prethodna se vježba ponavlja pet puta.

Olfaktivna i gustativna vježba: s obzirom na to da se miris i okus u mozgu zadržavaju mnogo dulje od ostalih oblika pamćenja i dokazano utječu na zdravlje, uvjerenja, ponašanje, stavove i produktivnost, istraživač se u intervenciji koristio upravo tim osjetilima. Svako slovo arapske abecede poprskano je nekim od prirodnih mirisa kao što su limun, jasmin, narcis i mošus. Za kombinaciju cvjetnih mirisa dokazano je da dvostruko uvećava brzinu čitanja (Wilmes i sur., 2008). Pri odabiru mirisnih slova, učenici su vođeni osobnim sklonostima, a odabranim su slovima poslije oblikovali riječi na magnetskoj ploči. Slova su pratili kažiprstom, pritom izgovarajući glasove. Učenici su svaku riječ kažiprstom ocrtavali u pješčaniku i potom ju ispisivali u zraku, pritom naglas izgovarajući odgovarajuće glasove. Svaka riječ oblikovana je s pomoću deserta raznih okusa, poput manga, naranče, marelice, jagode, banane i čokolade. Učenici su potom grupirali riječi iz odabranih odlomaka u skladu s njihovim osobnim ukusima. Učenici su pratili riječi, pritom izgovarajući odgovarajuće glasove.

Nakon spomenutih vježbi, istraživač je odabrao kratak odlomak kako bi učenici vježbali čitanje riječi u kontekstu, te čitanje i razumijevanje kratkih odlomaka. Učenici su prstima pokazivali svaku riječ. Istraživač je postavljao pitanja razumijevanja u skladu $s$ razinom razumijevanja pri čitanju, koja su obuhvaćala doslovno razumijevanje, interpretativno razumijevanje, razumijevanje na razini promišljanja i razumijevanje na razini ocjenjivanja. U kontrolnoj skupini istraživač je pokazivao riječi na ploči i svaku glasno izgovarao. Učenici su ponavljali svaku riječ, izgovarajući je najprije sporo, a potom brzo. Istraživač je riječi ispisivao u kratkim rečenicama, pa potom svaku rečenicu čitao naglas. Istraživač je svaki odlomak pročitao dva puta. Učenici su svaki odlomak čitali nekoliko puta. Istraživač je objasnio odlomak objašnjavajući značenje pojedinih riječi. Učenike je pozvao da sami osmisle rečenice koje uključuju značenje pojedinačnih riječi.

$S$ druge strane, $\mathrm{u}$ obzir su uzete osnovne karakteristike obogaćene okoline eksperimentalne skupine, modificirane $u$ skladu s učenjem prilagođenim mozgu: (a) 
odabir tekstova za čitanje u skladu s vlastitim interesima; (b) sigurna emocionalna okolina, lišena stresa i prijetnje; (c) pojedinačne sesije sadrže petominutnu mentalnu gimnastiku; (d) pauze su osigurane svakih 10 minuta; (e) prisutna je prirodna opuštajuća glazba; (f) nudi se pravodobna povratna informacija; (g) učionicu prožima ugodan miris limuna, cimeta i blage lavande; (h) ponuđene su boce s vodom.

\section{Analiza podataka}

Za sve varijable izračunati su osnovni opisni statistički parametri: aritmetička sredina (M) i standardna devijacija (D). Normalnost distribucije određena je KolmogorovSmirnovljevim testom (KS test). $Z$ vrijednosti KS testa u slučaju varijabli nisu bile statistički značajne. Pretpostavka o homogenosti varijable određena je Levenovim testom za jednakost varijable. F vrijednost Levenova testa nije bila statistički značajna za većinu varijabli, već je narušena u posttestiranjima brzine čitanja. Kako bi se odredio statistički značaj razlike između srednjih vrijednosti rezultata na posttestiranjima tečnosti čitanja i razumijevanja pri čitanju (nakon eliminiranja utjecaja predtestiranja) eksperimentalne i kontrolne skupine, koristile su se analize kovarijante (ANCOVAs), a predtestovi su se koristili kao kovarijati. S ciljem određivanja statističkog značaja razlike među inicijalnim i konačnim mjerenjima tečnosti čitanja i razumijevanja pri čitanju učenika, koristili su se upareni t-testovi. Uz metodu ANCOVA i neovisne i uparene t-testove autori su se također koristili parcijalnim eta kvadratom ( $\eta 2)$ kojim se mjeri veličina učinka. U kontekstu te statistike vrijednosti između 0,01 i 0,10 smatraju se malom veličinom učinka, vrijednosti između 0,10 i 0,30 smatraju se srednjom veličinom učinka, a vrijednosti više od 0,30 smatraju se velikom veličinom učinka. Prikupljeni rezultati testova analizirani su uz pomoć softwarea SPSS 17.

\section{Rezultati}

Cilj studije bio je istražiti utjecaj poučavanja utemeljenog na višeosjetilnosti i kombiniranog s okolinom prilagođenom mozgu na unapređenje tečnosti čitanja i razumijevanja pri čitanju disleksičnih učenika četvrtih razreda. Istraživači su slijedili odgovarajuće nacrte pred-i posttestiranja za obje skupine. S ciljem analiziranja podataka koristili su se standardna devijacija, neovisni i upareni t-testovi.

Rezultati neovisnog t-testa nisu otkrili značajnije razlike među dvjema skupinama na području brzine čitanja $(t=0,403, p=0,659)$, točnosti $(t=-0,315, p=0,755)$ ili razumijevanja pri čitanju $(\mathrm{t}=-0,437, \mathrm{p}=0,665)$, $\mathrm{u}$ odnosu na stanje prije početka treninga. Tablica 1 prikazuje srednju i standardnu devijaciju tečnosti čitanja i razumijevanja pri čitanju prema skupinama.

\section{Tablica 1}

Rezultati su prikazani u skladu s pitanjima istraživanja. S ciljem utvrđivanja statistički značajne razlike između eksperimentalne i kontrolne skupine na polju tečnosti čitanja (točnost i brzina čitanja) i razumijevanja pri čitanju nakon uklanjanja utjecaja predtestiranja, koristila se metoda ANCOVA. Rezultati su prikazani u Tablici 2. 


\section{Tablica 2}

Tablica 2 pokazuje da postoji statistička značajna razlika $(\mathrm{F}=166,16,53,12, \mathrm{i}$ $27,31 / \mathrm{p}=0,000,0,000$, te $0,000 / \eta 2=0,84,0,62,0,46) \mathrm{u}$ tečnosti čitanja (točnost $\mathrm{i}$ brzina čitanja) i razumijevanju pri čitanju između eksperimentalne i kontrolne skupine na posttestiranjima, u korist eksperimentalne skupine. Spomenuta razlika upućuje na to da poučavanje utemeljeno na višeosjetilnosti i kombinirano s okolinom prilagođenom mozgu može imati pozitivan utjecaj na tečnost čitanja (brzina i točnost čitanja) i razumijevanje pri čitanju disleksičnih učenika. Procijenjena srednja vrijednost za eksperimentalnu skupinu na posttestiranju točnosti čitanja iznosi 77,51, a za kontrolnu skupinu 31,71; za brzinu čitanja ta vrijednost iznosi 40,49 (eksperimentalna skupina), odnosno 9,35 (kontrolna skupina); za razumijevanje pri čitanju ta vrijednost iznosi 9,02 (eksperimentalna skupina), odnosno 7,53 (kontrolna skupina).

S ciljem utvrđivanja postojanja statistički značajne razlike među rezultatima predi posttestiranja tečnosti čitanja (točnost i brzina čitanja), i razumijevanja pri čitanju u eksperimentalnoj skupini, koristio se upareni t-test. Rezultati su prikazani u tablici 3.

\section{Tablica 3}

Tablica 3 pokazuje da postoji statistički značajna razlika $(t=-12,34,-20,01,-5,68$ / $\mathrm{p}=0,000,0,000,0,000 / \eta 2=0,90,0,96,0.65)$ u rezultatima pred- i posttestiranja tečnosti čitanja (brzina i točnost čitanja) i razumijevanja pri čitanju.

\section{Rasprava}

Rezultati usporedbi podataka o čitanju prema skupinama jasno pokazuju da je intervencija bila uspješna u unapređivanju tečnosti čitanja. Učenici u eksperimentalnoj skupini ostvarili su znatno veći napredak na polju tečnosti od učenika u kontrolnoj skupini, mjerimo li njihov napredak na polju: (a) točnosti čitanja i (b) brzine čitanja. Vrijednosti veličine učinka ukazuju na veći učinak intervencije.

Uzmemo li u obzir okolinu učenja, omogućavanje učenicima da sami biraju odlomke koje žele čitati uvećava njihovu motivaciju za čitanje. Kako se čini, elementi okoline prilagođene radu mozga u višeosjetilnim strategijama čitanja razvidni su među svim ispitanicama. Učenici u eksperimentalnoj skupini stoga su bili entuzijastični i spremni na sudjelovanje u aktivnostima, a učenici u kontrolnoj skupini bili su indiferentni prema postavljenim zadacima. Zapažanja istraživača otkrivaju da je učenicima u eksperimentalnoj skupini rad u učionici predstavljao zadovoljstvo. Osim toga, fizički pokret te taktilne, olfaktivne i gustativne aktivnosti izvedene $\mathrm{u}$ eksperimentalnoj skupini pokazali su se privlačnima za mlađe učenike. Tako, primjerice, praćenje riječi i slova dok ih se istodobno izgovara zaokuplja ruke učenika te omogućava dulju angažiranost i usredotočenost na ono što čine za vrijeme određene sesije. Učestalo pisanje u pijesku i u zraku omogućava učenicima da pisanju pristupaju uzbuđeno i motivirano. Pauze u kojima je dopušteno kretanje (jedan od elemenata okoline prilagođene radu mozga) poboljšavaju koncentraciju, vještine slušanja i raspon pažnje učenika (Peck i sur., 2005; Pellegrini i Bohn, 2005; Powell i sur., 2008). 
U kontekstu poučavanja utemeljenog na višeosjetilnosti, nekoliko je mogućih razloga za bolji uspjeh eksperimentalne skupine. Kao prvo, višeosjetilni trening stvara niz vizualno-auditivnih asocijacija pri učenju veza između grafema i fonema putem kinestetičkih, olfaktivnih i gustativnih aktivnosti. To pridonosi razvoju raspona pažnje za detalje na razini slova ili riječi, što pak pomaže pri aktivaciji riječi iz dugoročnog pamćenja (Nourbakhsh i sur., 2013). Kao drugo, spomenuti trening osigurava više povratnih informacija od učitelja, što pak ojačava neurološke putove u mozgu (Hazoury i sur., 2009; Uhry i Clark, 2005). Kao treće, kod te vrste učenja aktivira se više osjetila kao i višestrukih puteva učenja, što uvećava mogućnost stvaranja spona među neurološkim krugovima u mozgu koji obrađuju informacije potrebne za učinkovito čitanje.

Nacrt intervencijskoga programa u skladu je s preporukama kakve su u svojim metaanalizama istraživanja tečnosti, čiji ključni elementi uključuju (a) inkorporiranje korektivnih povratnih informacija, (b) sustavno napredovanje prema složenijom materijalu u trenutku kada učenici prelaze na višu razinu i (c) vježbe ponavljanja, ponudili Chard i sur. (2002), NPR (2000), Therrien (2004) i Yang (2006).

Rezultati su u skladu s rezultatima istraživanja kakva su proveli, npr. Chuen (2005), Duchock (1992), Foorman i sur. (1997), Giess (2005), Heidari i sur. (2012), Hook i sur. (2001), Jeyasekaran (2015), Joshi i sur. (2002), Kutrampos (1993), Litcher i Roberge (1979), Mehrabi i sur. (2014), Nourbakhsh (2014), Oakland i sur. (1998), Stoner (1991) i Westrich-Bond (1993).

Rezultati usporedbe razumijevanja pri čitanju među skupinama jasno ukazuju na uspješnost intervencije u unapređivanju razumijevanja pri čitanju. Učenici u eksperimentalnoj skupini ostvarili su znatno veći napredak na polju razumijevanja od učenika u kontrolnoj skupini, mjeren njihovim rezultatima na testu razumijevanja pri čitanju. Vrijednost veličine učinka ukazuje na velik učinak intervencije.

Proces učenja može biti značajniji i učinkovitiji ako su disleksični učenici u mogućnosti aktivirati sva svoja osjetila. Svako osjetila predstavlja put u njihovim mozgovima. Što više putova u mozgu, to će proces učenja biti kvalitetniji (Subramaniam i sur., 2013). Mayer i Moreno (1998) ustanovili su da su rezultati učenja bolji ako se ono što se uči predstavlja putem više modaliteta (npr. vizualnim i verbalnim putem) i da zajednička obrada informacija putem više modaliteta poboljšava sposobnost prisjećanja i razumijevanja među učenicima (Mousavi i sur., 1995). Na temelju niza studija provođenih među brojnim učenicima zaključuju se da postoji pozitivna veza između bolje tečnosti i boljeg razumijevanja pri čitanju (Chard i sur., 2002; Kuhn i Stahl, 2003, 2004; National Reading Panel, 2000; Rasinski i Hoffman, 2003; Rasinski i sur., 2011; Therrien, 2004). Istraživači sugeriraju da će poboljšana tečnost učenicima pomoći da više vlastitih kognitivnih sposobnosti usmjere na razumijevanja pročitanog (LaBerge i Samuels, 1974).

\section{Ograničenja i smjernice za buduća istraživanja}

Ovdje predstavljeno istraživanje ima nekoliko ograničenja. Prvo: uzorak na kojemu je vršeno istraživanje nije nužno reprezentativan za sve disleksične učenike zbog male 
veličine i zastupljenog spola (isključivo muški sudionici). Pregled literature o disleksiji, pak, otkriva da rodni omjer disleksije iznosi 2:1 ili 3:1. Buduća istraživanja trebala bi se usredotočiti na veće uzorke i u jednakoj mjeri obuhvatiti sudionike oba spola. Drugo: ovdje predstavljeno istraživanje pri procjeni tečnosti čitanja mjerilo je jedino brzinu i točnost čitanja. Međutim, brzina i točnost nisu jedine komponentne tečnosti čitanja - valja spomenuti i prozodiju (izraz koji ima značenje) kao treću komponentnu. Buduća istraživanja trebala bi ispitati učinkovitost ovdje opisane intervencije na sve komponente tečnosti čitanja. Treće: ovdje predstavljeno istraživanje koristilo se samo jednim mjerilom razumijevanja pri čitanju. Korištenje višestrukim procjenama razumijevanja pri čitanju moglo bi uvećati točnost mjerenja razumijevanja pri čitanju. Buduća bi se istraživanja stoga trebala koristiti višestrukim procjenama razumijevanja pri čitanju. Četvrto ograničenje manjak je kontrole nad varijablama vezanim uz razumijevanje pri čitanju, kao što su verbalno radno pamćenje i metakognitivne vještine. Buduća bi istraživanja trebala kontrolirati vezane varijable razumijevanja pri čitanju.

\section{Zaključak}

Istraživanje nudi uvid u prednosti kombiniranja višeosjetilnog poučavanja i učenja prilagođenog mozgu u kontekstu usvajanja vještina čitanja među učenicima s disleksijom. Rezultati pokazuju da su intervencijom uspješno unaprijeđene dvije podvještine tečnosti čitanja, točnije točnost čitanja i brzina čitanja s velikim učinkom. Rezultati također sugeriraju da je intervencija unaprijedila razumijevanje pri čitanju. Svakome od učenika - sudionika dijagnosticiran je poremećaj čitanja, te se svaki od njih dulje vrijeme bori s poteškoćama u čitanju. Unatoč prijašnjim poteškoćama, primijenjena intervencija imala je pozitivan učinak na njihovu uspješnost u čitanju, što nas navodi na zaključak da bi ta vrsta intervencije mogla predstavljati obećavajuću mogućnost za buduće programe za učenike s disleksijom. Iako je velik učinak podataka o čitanju posljedica ovdje opisane intervencije, veći učinak mogao bi se javiti i uslijed duljeg trajanja pojedinačnih sesija, odnosno duljeg trajanja cjelokupne intervencije. 